\title{
Bioaccumulation potential and health risk assessment of heavy metals in Corchorus olitorius L. (Malvaceae) and Amaranthus hybridus L. (Amaranthaceae) obtained from a selected dump site in Akure, Nigeria
}

\section{Foluso Ologundudu*, Adegbite Tobi and Omotola Fopeyemi}

Department of Biology. Federal University of Technology. Akure. Nigeria. *Email: akinbodefoluso@gmail.com.

\begin{abstract}
Heavy metal contamination of polluted site has become a recurring decimal globally posing a threat to human life and biodiversity. This study was carried out to investigate the bioaccumulation potential and health risk assessment associated with the consumption of two indigenous vegetables Corchorus olitorius L. (Malvaceae) and Amaranthus hybridus (Amaranthaceae) in Akure. Initial pre soil analysis showed that the heavy metal concentration were above the safe limit as recommended by World Health Organization (WHO). The heavy metals investigated include $\mathrm{Cr}, \mathrm{Ni}, \mathrm{Cd}, \mathrm{Fe}$ and $\mathrm{Pb}$ for their bioaccumulation factor to provide baseline data regarding environmental safety and suitability of the vegetables for human consumption. Translocation factor, Daily Intake of Metal (DIM), Health Risk Index (HRI) and Oral Refrence Dose (RFD) were calculated following standard methods. This study concludes that different vegetables accumulate and translocate variable amount of heavy metals from the soil into their tissues. Hence, it is not advisable to consume vegetable samples collected from this site based on the permissible limits as recommended by World Health Organization (WHO).
\end{abstract}

Keywords: Bioaccumulation; Biodiversity; Environmental safety; Health risk index; Translocation.

\section{Introduction}

Bioaccumulation of toxic heavy metals in human body system is very dangerous to human health as it could cause damage to some of the visceral
Received

February 10, 2019

Accepted

April 14, 2019

Released

April 30, 2019

Full Text Article

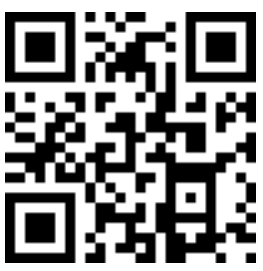

ORCID

(D) $0000-0003-1075-6357$

Foluso Ologundudu

D 0000-0001-5936-2215

Adegbite Tobi

(D) 0000-0002-3727-5505

Omotola Fopeyemi 
accumulation of heavy metals could lead to development of cancers (Gupta, 2008). Although, most heavy metals are contained in the soil but may not come only from the bed rock of the soil, but also from solid or liquid waste deposits, agricultural inputs and industrial emissions (Wilson and Pyatt, 2007). Excessive discharge of these waste products into the soil could lead to contamination and accumulation of the toxic heavy metals in the soil which in turn lead to their adsorption by plants.

Heavy metals are major contaminants of agricultural produce and could be consider as an important environmental problem in the world (Zaidi et al., 2005) that can reduce production of quality food (Zheljazkov et al., 2006).

Plant growth is dependent on the cycle of nutrients including trace elements, from soil to plants (Mohamed et al., 2003). Vegetables, especially the leafy ones accumulate higher amount of heavy metals due to the fact that they absorb these metals in their leaves (Bagdatlioglu et al., 2010). Vegetables accumulate heavy metals in their edible and non-edible parts at very high amount that can be toxic to both animas and human health (Guerra et al., 2012). For instance, the consumption of food contaminated with heavy metal can seriously deplete some essential nutrients in the body causing a decrease of immunological defenses, disabilities associated with malnutrition and a high prevalence of upper gastrointestinal cancer (Oliver, 1997).

Research carried out in Copsa Mica and Baia Mare, Romania, revealed that soil and vegetables contaminated with $\mathrm{Pb}$ and $\mathrm{Cd}$ significantly contributed to decrease human life expectancy (9-10 years) within the affected areas (Lacatusu et al., 1996). Among the heavy metals, cadmium and lead are the most toxic to human (Volpe et al., 2009). Although, some heavy metals such as $\mathrm{Cr}$, $\mathrm{Co}$ and $\mathrm{Ni}$ are essential to human, but may cause metabolic disorder when they are present in higher concentration in the body (Guerra et al., 2012). Excessive accumulation of heavy metals in soils may not only contaminate the soil, but may also affect food quality and safety. So, it is essential to monitor food quality, given that plant uptake is one of the main route through which heavy metals get into food products (Antonious and Kochhar, 2009).

Therefore, this research in aimed at investigating the concentrations and accumulation of $\mathrm{Cr}, \mathrm{Ni}, \mathrm{Cd}, \mathrm{Fe}$ and $\mathrm{Pb}$ in the edible parts of different vegetable species grown on dump sites and to investigate the health risks of heavy metal consumption by consumers.

\section{Materials and methods}

\section{Study area}

The study was conducted in a newly developing dump site opposite North gate area of the Federal University of Technology, Akure. Akure is the capital city of Ondo State, located in the rain forest zone with average annual rainfall of $2,378 \mathrm{~mm}$, average annual temperatures ranging from 25.2 to $28.1^{\circ} \mathrm{C}$ and relative humidity of $80 \%$.

\section{Collection of vegetable seeds}

Pure seeds of Amaranthus hybridus and Corchorus olitorius (10 g each) were purchased from Oja Oba market in Akure, Ondo State. After purchase, the seeds were taken to the Biology Department of the Federal university of Technology, Akure for identification and authentication.

\section{Vegetable planting}

The seeds were planted at the polluted dump site. The seeds were cultivated at three different levels $(2 \mathrm{~m}, 4$ $\mathrm{m}$ and $6 \mathrm{~m}$ ) from the main garbage hill using a hoe and a cutlass to make the vegetable bed. The control site was located at the Screen house of the department of Biology, Federal University of Technology, Akure. 


\section{Soil sample collection}

Soil samples were collected at each level as stated above for heavy metal analysis before planting, using a soil auger at a depth of $30 \mathrm{~cm}$. the samples were stored in clean polythene bags and later transferred to the laboratory. The soil samples were airdried, grounded and passed through 2 $\mathrm{mm}$ sieve for heavy metal analysis.

\section{Vegetable sample collection}

15 vegetable samples were present (1 $\mathrm{kg}$ edible part of each) including 3 replicates of each leafy vegetable type collected from each level at the study site. Simultaneously, 3 replicate samples of each vegetable were harvested at maturation. shoot samples of the vegetables were washed with deionised water, oven dried at $70{ }^{\circ} \mathrm{C}$ and then pulverized into fine powder with pestle and mortar.

\section{Heavy metal analysis}

Chromium (Cr), Nickel (Ni), Cadmium (Cd), Iron (Fe), and lead (Pb) were analysed. $1 \mathrm{~g}$ of the soil sample was digested with $15 \mathrm{~mL}$ of aqua regia $\left(\mathrm{HNO}_{3}\right.$ : $\mathrm{HCl}$ in 3:1 ratio), also, one gram each of air-dried stem and root sample of $A$. hybridus and C. olitorius were digested with $15 \mathrm{~mL}$ of triacid mixture $\left(\mathrm{HNO}_{3}: \mathrm{H}_{2} \mathrm{SO}_{4}: \mathrm{HClO}_{4}\right.$ in $5: 1: 1$ ratio) at $80^{\circ} \mathrm{C}$ till a transparent solution was obtained (Allen et al., 1986). The digested samples were filtered and diluted with de-ionized water up to 50 $\mathrm{mL}$ and analyzed by flame atomic absorption spectrophotometer (AAS) (Agilent 240 FS AA model).

The bioaccumulation factor (BAF) which is the ratio of heavy metal concentration of crop to soil (Zhuang et al., 2013) was calculated using the formula:

$$
\mathrm{BAF}=\frac{C \text { plant }}{C_{\text {soil }}}
$$

Where $C_{\text {plant }}=$ concentrations of heavy metal in edible part of the vegetable $(\mathrm{mg} / \mathrm{kg})$;

$C_{\text {soil }}=$ concentrations of heavy metal in soil $(\mathrm{mg} / \mathrm{kg})$.

\section{Daily Intake of Metal (DIM)}

Daily Intake of metals was calculated using the formula:

$$
\text { DIM }=\frac{\text { Cmetal } \times \text { Cfactors } \times \text { Dintack }}{\text { Bweight }}
$$

Where

$$
\mathrm{C}_{\text {metal }}=\text { metal }
$$
concentrations in the vegetable sample; $\mathrm{C}_{\text {factors }}=$ concentration factors; $\mathrm{D}_{\text {intake }}=$ daily intake of the vegetable samples and $B_{\text {weight }}=$ the average body weight.

The concentration factor $\left(C_{f}\right)$ of 0.085 was used for the conversion of fresh vegetables to dry weight. The average daily intake of the vegetable was $0.428 \mathrm{~kg}^{-1} \cdot \mathrm{d}^{-1}$ and the average body weight for the adult population was 62.9 $\mathrm{kg}$.

\section{Health Risk Index (HRI)}

HRI refers to the intake of metals in the vegetables to the Oral Reference Dose (RFD) (USEPA, 2002) was calculated using the formula:

$$
\text { HRI }=\frac{\text { DIM }}{\text { RFD }}
$$

An HRI greater than 1 for any metal in food crop indicates that the consumed population is at health risk.

\section{Target Hazard Quotient (THQ)}

THQ was calculated following the procedure of Abdu et al., 2011.

$$
\mathrm{THQ}=\frac{\mathrm{Efr} \times \mathrm{ED} \times \mathrm{FI} \times \mathrm{MC}}{\mathrm{RFD} \times \mathrm{BW} \times \mathrm{AT}} \times 0.001 .
$$

Where Efr is the exposure frequency (365 days year ${ }^{-1}$ ), ED is the Exposure Duration (60 years for adult), FI is the food ingestion, MC is the Metal Concentration in the food $\left(\mathrm{mgkg}^{-1}\right)$ fresh 
weight, RFD is the oral reference dose $\left(\mathrm{mgkg}^{-1}\right.$ day $\left.^{-1}\right)$, BW is the average body weight for an adult $(60 \mathrm{~kg})$ and AT is the average exposure time for noncarcinogenic effects (365 days year $^{-1} \times$ number of exposure year.

Health risk assessment of heavy metals in vegetable

Contamination Factor (CF):

$$
\mathrm{CF}=\frac{\mathrm{Cm}}{\text { Cbackground }}
$$

Where $\mathrm{C}_{m}$ is the metal in the vegetable sample around the site and $C_{\text {background }}$ is the background concentration of the metal in the soil.

\section{Bioconcentration factor}

BCF was calculated using the formula:

$$
\mathrm{BCF}==\frac{\text { Cvegetable }}{\text { Csoil }}
$$

Where $C_{\text {plant }}=$ concentrations of heavy metal in edible part of the vegetable;

$C_{\text {soil }}=$ concentrations of heavy metal in soil.

\section{Transfer factor}

$$
T F=\frac{C_{\text {above the ground } d \text { parts }}}{C_{\text {root }}}
$$

\section{Statistical analysis}

Data obtained from this research was analysed using IBM Statistical Package for Social Sciences (SPSS) version 16.0 (Chicago, USA). Pearson correlation coefficient was used to analyze the correlation between heavy metals in soil. All charts were created using Microsoft excel.

\section{Results}

\section{vegetables}

Morphological parameters of Number of leaves of Corchorus olitorius. The average numbers of leaves of Corchorus olitorius grown (Figure 1). There is significant difference ( $\mathrm{p} \leq 0.05$ ) in the average number of leaves of Corchorus olitorius in the control site with respect to other levels of contamination.

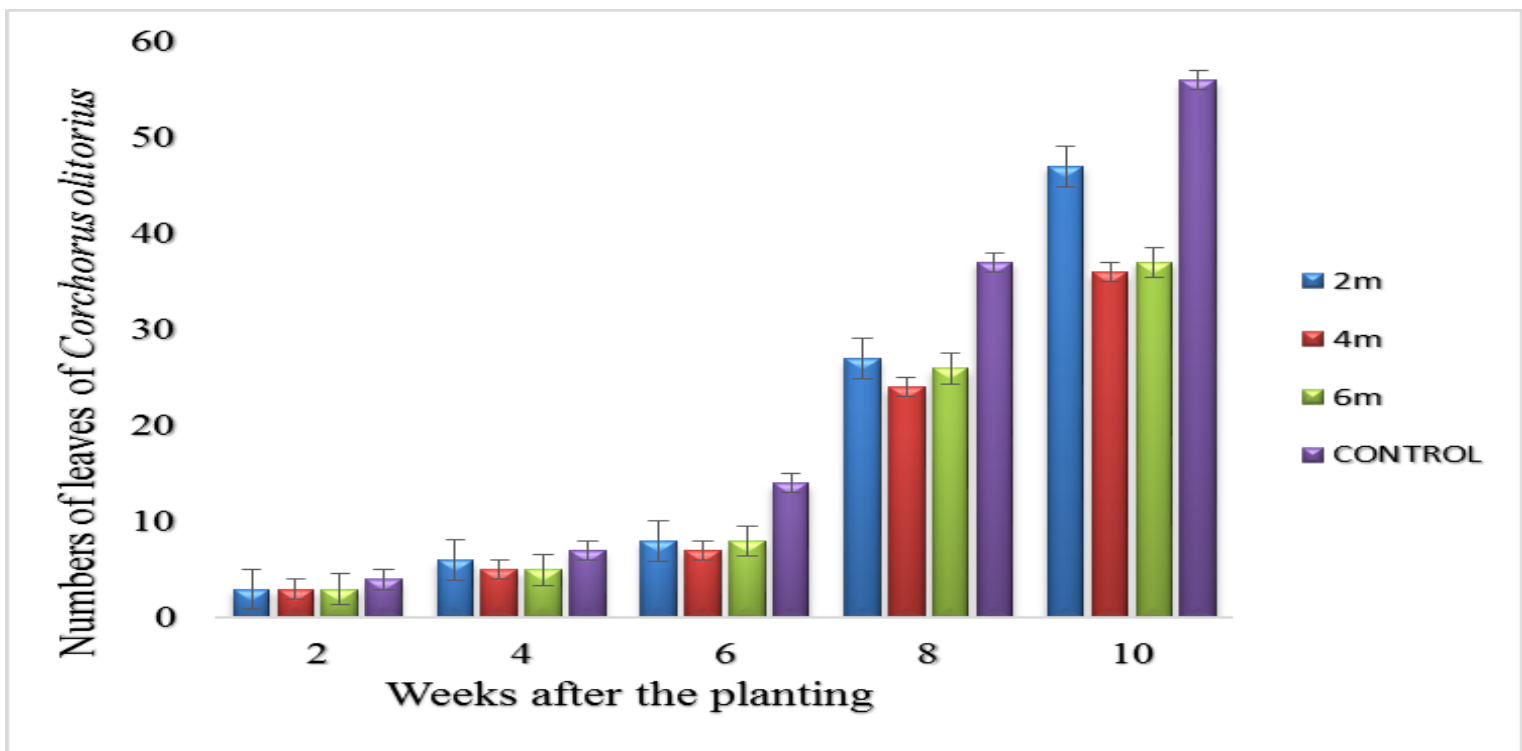

Figure 1. Numbers of leaves of Corchorus olitorius at different levels of contamination. 
Number of leaves of Amaranthus hybridus. The average numbers of leaves of Amaranthus hybridus shows that there is no significant difference in the different levels of contamination of the samples investigated (Figure 2).

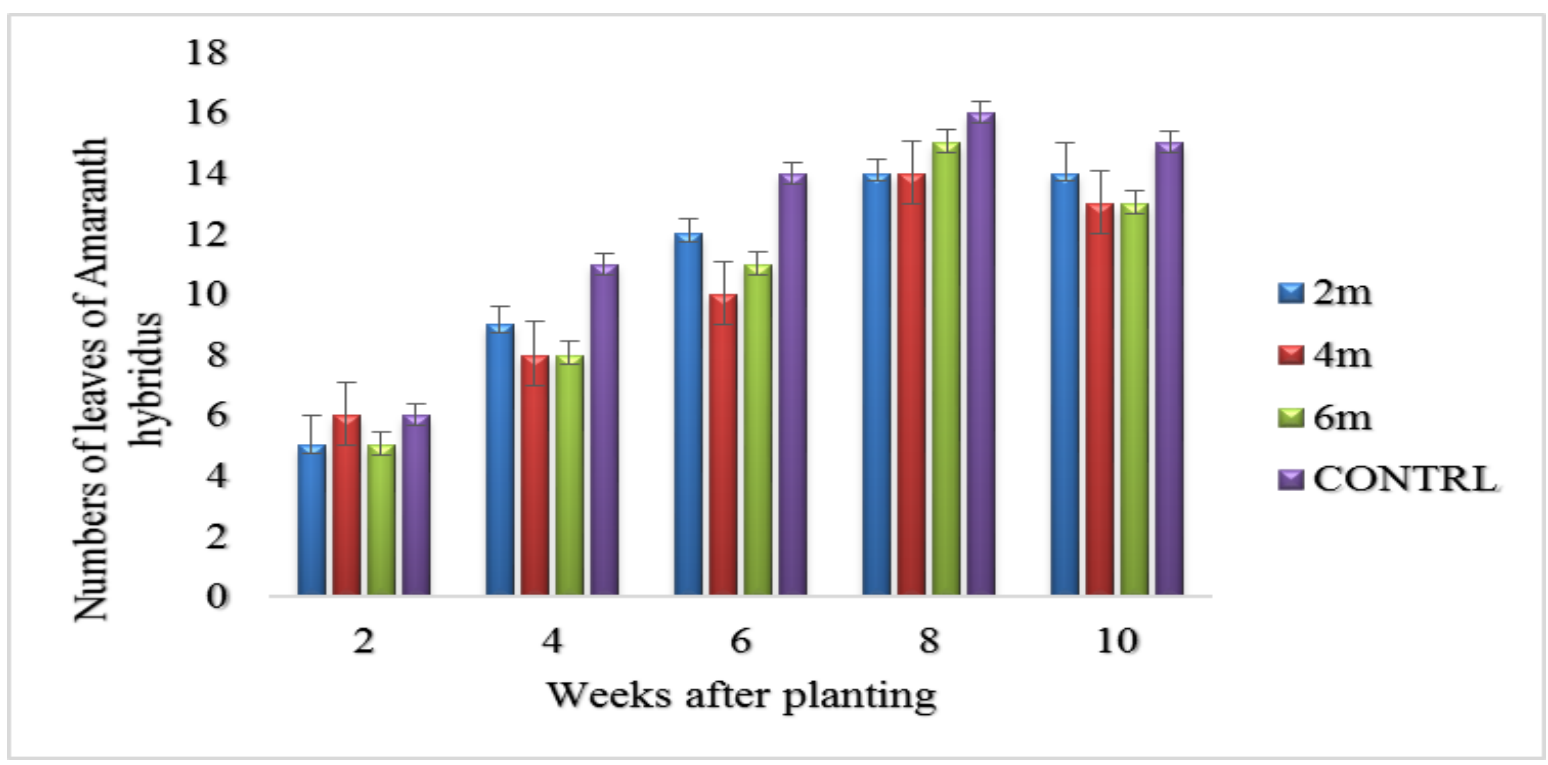

Figure 2. Numbers of leaves of Amaranthus hybridus at different levels of contamination.

\section{olitorius}

Moisture content of Corchorus

The moisture content of

C. olitorius at different levels of contamination (Figure 3). There was a decrease in the moisture content of C. olitorius with increasing levels of contamination.

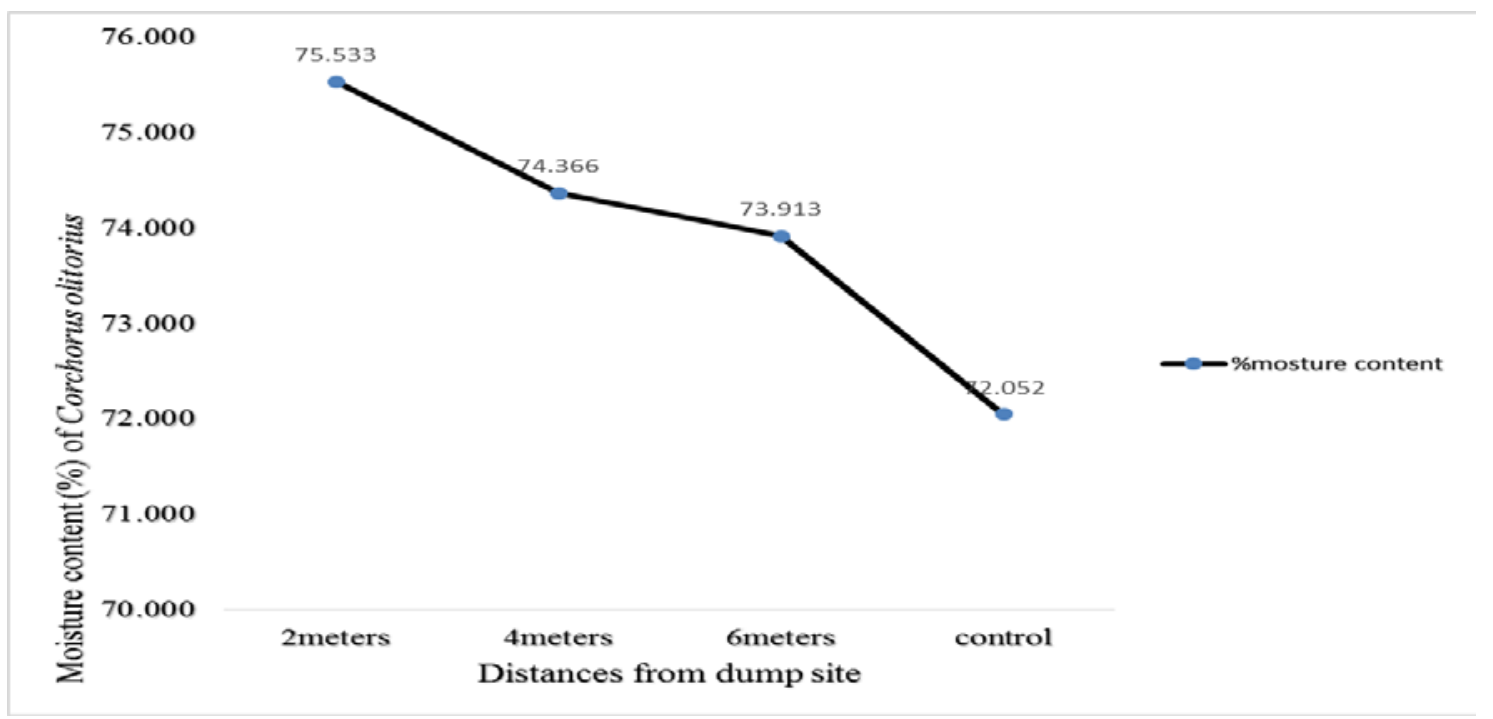

Figure 3. Moisture content (\%) of Corchorus olitorius at different levels of contamination. 


\begin{tabular}{|c|c|}
\hline Moisture content of & olitorius except that the moisture content \\
\hline Amaranthus hybridus & of Amaranthus hybridus was relatively \\
\hline $\begin{array}{l}\text { Figure } 4 \text { shows the moisture } \\
\text { content of Amaranthus hybridus at } \\
\text { different contamination levels. Similar }\end{array}$ & $\begin{array}{l}\text { higher at } 2 \mathrm{~m} \text { contamination level and no } \\
\text { significant change in moisture content at } \\
6 \mathrm{~m} \text { and the control site. }\end{array}$ \\
\hline
\end{tabular}
trend was observed as in Corchorus

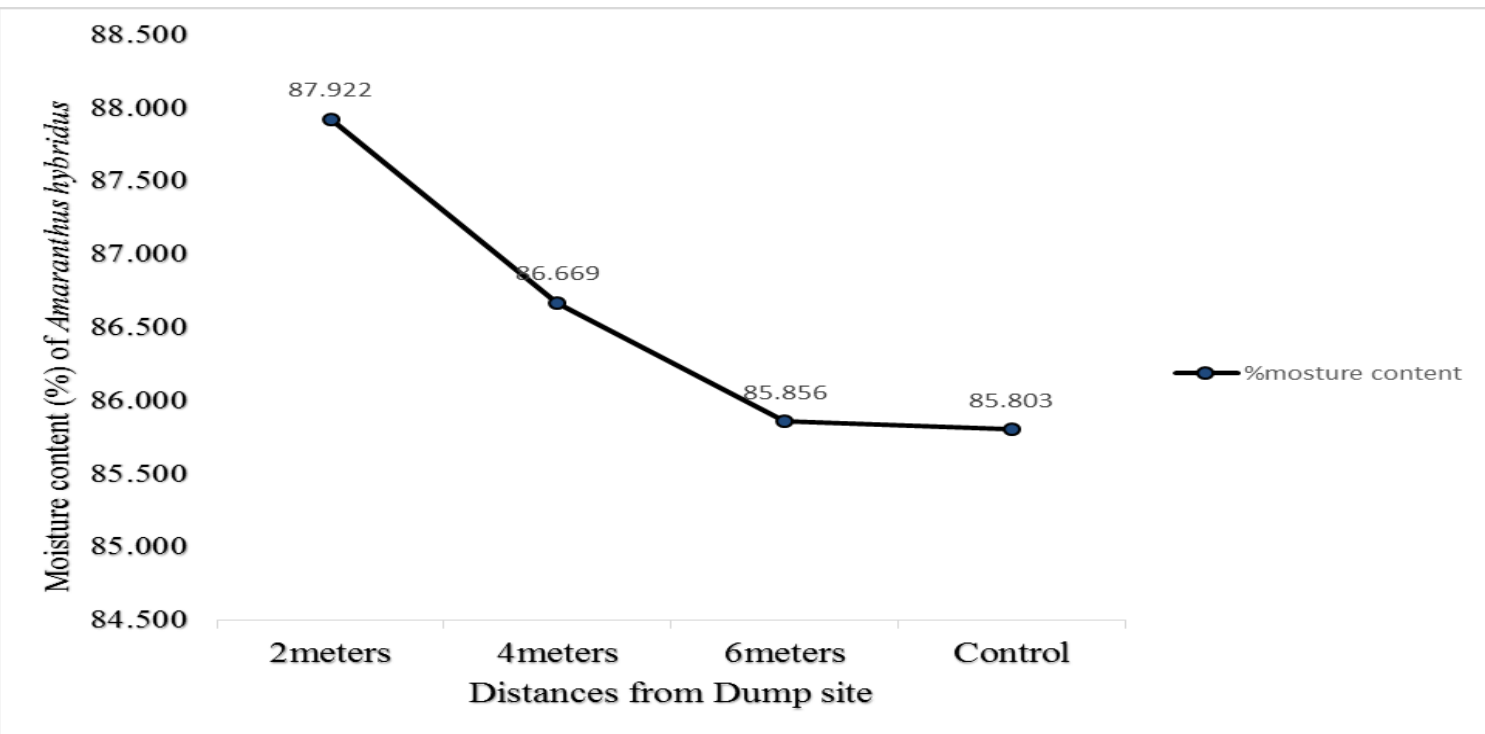

Figure 4. Moisture content (\%) of Amaranthus hybridus at different levels of contamination.

\section{samples \\ Moisture content of soil \\ The moisture content of soil} samples followed a decreasing order of magnitude $(38.2<26.1<23.1<12.0)$ as against the increasing levels of contamination $(2 \mathrm{~m}, 4 \mathrm{~m}, 6 \mathrm{~m}$ and the control) (Figure 5, Table 1).

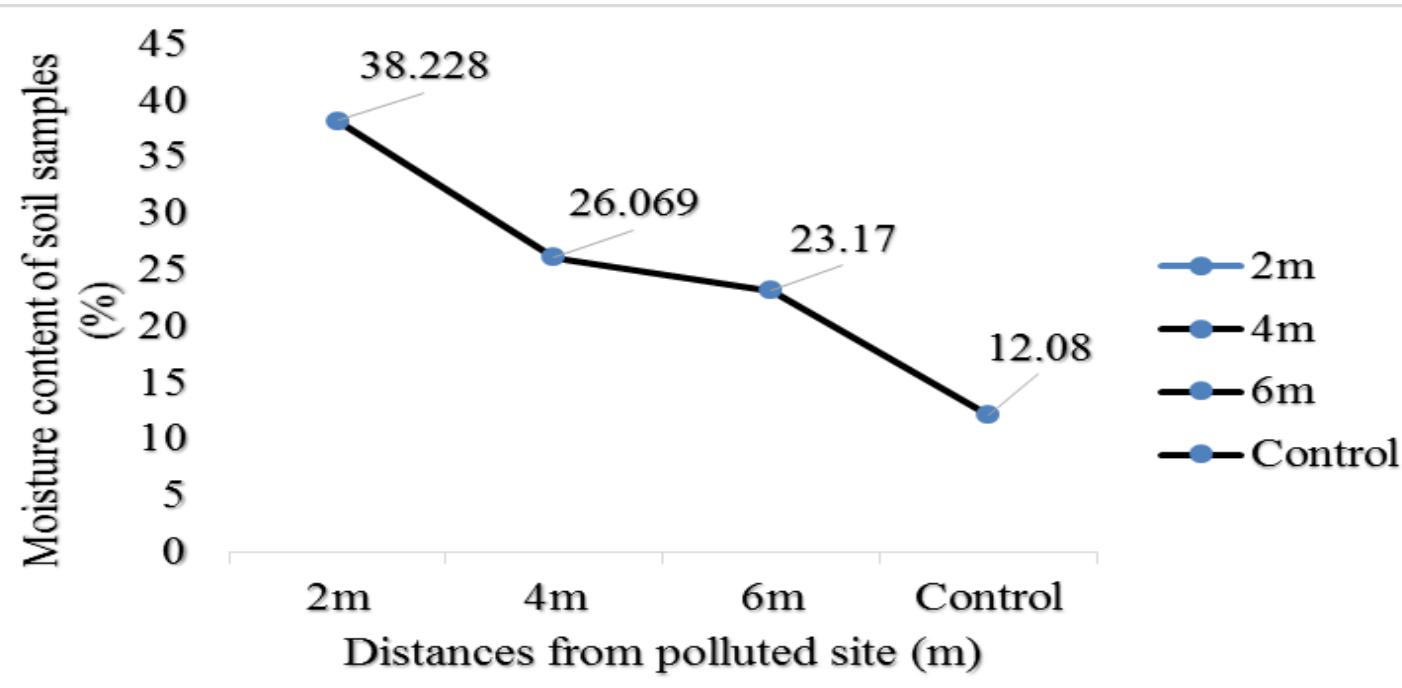

Figure 5. Moisture content (\%) of Amaranthus hybridus at different levels of contamination. 
Table 1. Mean Bioconcentration Factor $(\mathrm{mg} / \mathrm{kg}$ ) of some selected heavy metals (Fe, $\mathrm{Pb}, \mathrm{Ni}, \mathrm{Cr}$ and Cd) in Amaranthus hybridus at different levels or distances from polluted site.

\begin{tabular}{|c|c|c|c|c|c|c|}
\hline Metals & $2 \mathrm{~m}$ & $4 \mathrm{~m}$ & $6 \mathrm{~m}$ & Control & Mean & Sig \\
\hline $\mathrm{Fe}$ & $0.2894 \pm 0.01$ & $2.7869 \pm 0.002$ & $0.2853 \pm 0.04$ & $0.0526 \pm 0.002$ & $1.7872 \pm 0.02$ & $\mathrm{~S}$ \\
\hline $\mathrm{Pb}$ & $0.202 \pm 0.003$ & $0.3125 \pm 0.0$ & $0.2 \pm 0.0022$ & 0.00 & $0.2383 \pm 0.03$ & S \\
\hline $\mathrm{Ni}$ & BDL & BDL & BDL & BDL & BDL & - \\
\hline $\mathrm{Cr}$ & BDL & BDL & BDL & BDL & BDL & - \\
\hline $\mathrm{Cd}$ & BDL & BDL & BDL & BDL & BDL & - \\
\hline
\end{tabular}

Each value is the mean of 3 replicates \pm Standard Error; BDL = Below Detection Level; $\mathrm{S}=$ Significant; NS = Non significant

$\begin{gathered}\text { Translocation factor of } \\ \begin{array}{c}\text { olitorius were below the detectable limit } \\ \text { vegetable samples }\end{array} \\ \text { Translocation Factor (TF) of in both vegetable samples } \\ \text { (Table 2). }\end{gathered}$
Amaranthus hybridus and Corchoru

Table 2. Translocation Factor (TF) of Amaranthus hybridus and Corchorus olitorius

\begin{tabular}{lcc}
\hline \multirow{2}{*}{ Metals } & \multicolumn{2}{c}{ Translocation Factor } \\
\cline { 2 - 3 } & Amaranth hybridus & Corchorus olitorius \\
\hline $\mathrm{Fe}$ & $0.02-0.050$ & $0.041-0.320$ \\
$\mathrm{~Pb}$ & $0.14-0.170$ & $0.010-0.110$ \\
$\mathrm{Cr}$ & $\mathrm{ND}$ & $\mathrm{ND}$ \\
$\mathrm{Cd}$ & $\mathrm{ND}$ & $\mathrm{ND}$ \\
$\mathrm{Ni}$ & $\mathrm{ND}$ & $\mathrm{ND}$ \\
\hline
\end{tabular}

$\mathrm{ND}=$ Not detected

\section{Health risk assessment}

The daily intake of metal (DIM) and Health risk index (HRI) of the metals in the vegetable samples is shown in
Figure 3. It was not detected in $\mathrm{Cr}, \mathrm{Cd}$ and Ni. The HRI and DMI was higher in Amaranth than in Corchorus for $\mathrm{Fe}$ as against $\mathrm{Pb}$.

Table 3. Daily intake of metal (DIM) and Health risk index (HRI) of Amaranthus hybridus and Corchorus olitorius.

\begin{tabular}{lcccc}
\hline \multirow{2}{*}{ Metal } & \multicolumn{2}{c}{ DIM } & \multicolumn{2}{c}{ HRI } \\
\cline { 2 - 5 } & Amaranth & Corchorus & Amaranth & Corchorus \\
\hline $\mathrm{Fe}$ & $1.2 \mathrm{E}-0.2$ & $0.8 \mathrm{E}-0.2$ & $2.2 \mathrm{E}-0.5$ & $1.4 \mathrm{E}-0.1$ \\
$\mathrm{~Pb}$ & $1.9 \mathrm{E}-0.2$ & $0.3 \mathrm{E}-0.1$ & $1.7 \mathrm{E}-0.2$ & $1.2 \mathrm{E}-0.2$ \\
$\mathrm{Cr}$ & $\mathrm{ND}$ & $\mathrm{ND}$ & $\mathrm{ND}$ & $\mathrm{ND}$ \\
$\mathrm{Cd}$ & $\mathrm{ND}$ & $\mathrm{ND}$ & $\mathrm{ND}$ & $\mathrm{ND}$ \\
$\mathrm{Ni}$ & $\mathrm{ND}$ & $\mathrm{ND}$ & $\mathrm{ND}$ & ND \\
\hline
\end{tabular}

$\mathrm{ND}=$ Not detected 
Target Hazard Quotient for both Amaranthus hybridus and Corchorus olitorius for the metals investigated (Table 4). The THQ was slightly higher in Amaranth than in Corchorus. However, it was below detectable limit (BDL) in $\mathrm{Cr}$, $\mathrm{Cd}$ and $\mathrm{Ni}$. Table 5 shows the oral reference dose and it was found that the RFD value of Corchorus spp. was higher than that of Amaranthus spp.

Table 4. Target Hazard Quotient (THQ) of Amaranthus hybridus and Corchorus olitorius.

\begin{tabular}{lcc}
\hline \multirow{2}{*}{ Heavy Metals in plants tissues } & \multicolumn{2}{c}{ THQ } \\
\cline { 2 - 3 } & Amaranthus hybridus & Corchorus olitorius \\
\hline $\mathrm{Fe}$ & 0.75 & 0.7 \\
$\mathrm{~Pb}$ & 1.18 & 1.2 \\
$\mathrm{Cr}$ & $\mathrm{BDL}$ & $\mathrm{BDL}$ \\
$\mathrm{Cd}$ & $\mathrm{BDL}$ & $\mathrm{BDL}$ \\
$\mathrm{Ni}$ & $\mathrm{BDL}$ & $\mathrm{BDL}$ \\
\hline
\end{tabular}

Table 5. RDA and RFD values of Amaranthus hyridus and Corchorus olitorius.

\begin{tabular}{lcccc}
\hline \multirow{2}{*}{ Metals } & \multicolumn{2}{c}{ RDA } & \multicolumn{2}{c}{ RFD } \\
\cline { 2 - 5 } & A. hybridus & C. olitorius & A. hybridus & C. olitorius \\
\hline $\mathrm{Fe}$ & $4.0-6.0$ & $5.0-7.5$ & 0.24 & 0.52 \\
$\mathrm{~Pb}$ & $1.2-2.1$ & $4.0-6.2$ & 0.57 & 0.76 \\
$\mathrm{Cr}$ & BDL & BDL & BDL & BDL \\
$\mathrm{Cd}$ & BDL & BDL & BDL & BDL \\
$\mathrm{Ni}$ & BDL & BDL & BDL & BDL \\
\hline
\end{tabular}

\section{Discussion}

To assess the health risk of each pollutant, it is important to estimate the level of exposure by detecting the routes of exposure to target organism. These are several possible pathways of exposure to humans, but among them, the food chain is the most important pathway. In this study, the pathway considered for $\mathrm{Cr}, \mathrm{Pb}, \mathrm{Ni}, \mathrm{Cd}, \mathrm{Fe}$ were for vegetable consumption. The DIM values were estimated according to the average vegetable consumption for adults (Table 4) and composed with the recommended daily intakes (WHO, 1996; Trumbo et al, 2001). The results for the evaluation of the DIM and HRI from the heavy metal contaminated vegetable are presented in Table 4. The result showed that DIM and HRI values were higher in the vegetable plant. The DIM of the vegetable samples ranged from $1.2 \mathrm{E}-0.2$ to $1.9 \mathrm{E}-0.2,1.7 \mathrm{E}-$ 0.3 to $1.2 \mathrm{E}-0.3$ to $1.6 \mathrm{E}-0.2 ; 1.8 \mathrm{E}-0.2$ mg.kg-1 ${ }^{-1}$. ${ }^{2}$ son $^{-1} \cdot \mathrm{d}^{-1}$ for $\mathrm{Fe}, \mathrm{Pb}, \mathrm{Cr}, \mathrm{Cd}, \mathrm{Ni}$ (Table 5). Similarly in Amaranth, the HRI values for $\mathrm{Fe}, \mathrm{Pb}, \mathrm{Cr}, \mathrm{Cd}$, Ni ranged from 0.8 E-0.2, 0.3E-0.1, 0.6E-0.1.

The mean concentration factors of $\mathrm{Pb}, \mathrm{Fe}, \mathrm{Ni}, \mathrm{Cr}, \mathrm{Cd}$ in the vegetable samples were $1.65,1.20,0.0,0.0$ and 0.0 mg.kg-1 (Table 1 and 2). The present study indicated that all of the heavy metal concentrations in the polluted sites were higher than the permissible limits in both vegetable samples. Various Scientist have reported elevated levels of heavy metals on sewage and industrial effluents-irrigated vegetables (Mohammad et al., 2007). The findings from this study are in conformity with the reports of Singh and Kumar (2006). Although, the polluted sites contain low levels of the heavy metals, the plant 
samples showed higher values due to accumulation (Gupta et al., 2010). High levels of heavy metals in vegetable were observed because the sewage water was enriched with heavy metals thus polluting the soil and consequently the vegetables. These findings are a clear reflection of waste water ingestion and the subsequent accumulation of heavy metals in the vegetable. Amaranthus hybridus and Cochorus olitorius had maximum metal concentration for $\mathrm{Pb}, \mathrm{Fe}$ except for $\mathrm{Cd}, \mathrm{Cr}$ and $\mathrm{Ni}$ because of the large surface area of their leaves, their higher transportation and faster growth rate which enhances the metal translocation in leafy vegetable.

The accumulation factor for $\mathrm{Fe}$, $\mathrm{Pb}$ are greater than one at $6 \mathrm{~m}$ from the study site. Those metals that have a higher transfer factor migrate to the edible parts of the plants easily than those with a low transfer factor (Luo et al., 2011). Higher TF value is a clear reflection of possible health risk in the populace around the polluted site. Findings from this research indicate that uptake of heavy metals by food crops did not increase linearly with the increasing metal concentrations in the soil (Rattan et al., 2005).

The oral reference dose (RFD) is the daily exposure of individuals to toxins or pollutants that can pose no appreciable hazard over their lifetime. The RFD values for the toxic metals $\mathrm{Cd}$, $\mathrm{Cr}, \mathrm{Ni}, \mathrm{Pb}$ and $\mathrm{Fe}$ are 1.2E-0.5 1.5E-0.2, 1.9E-2.1 2.4E- 3, 2.8E-3.2 mg.kg-1.d-1, respectively (EPA -IRIS, 2006). In this study, the heavy metals except for $\mathrm{Cr}$ and $\mathrm{Ni}$ have HRI $>1$ indicating a possible health risk through the consumption of $\mathrm{Pb}$ and $\mathrm{Fe}$ in their diet. However, $\mathrm{Cd}$ and $\mathrm{Pb}$ are considered to be non-essential metals contributing to health hazards even at extremely low concentrations (Ikeda et al., 2010). Findings from this research did not agree with these reports. Zhuang et al. (2009) also reported a HRI value for $\mathrm{Cd}$ and $\mathrm{Pb}$ that is above the permissible limits in vegetables and cereals.
The THQ has been recognized as a useful parameter for evaluating the risk associated with the consumption of metal- contaminated food crops. (Agbenin et al., 2009). The results obtained in this study were above this limit and suggested possible metal contamination through the vegetable plant. According to the THQ values, Cd and $\mathrm{Pb}$ present in consumed plant has the potential to pose a health risk to the local population (Honguchi et al., 2004) have suggested that the ingested heavy metal may be excreted with the remainder accumulating in body tissues where they can affect human health. The present study is quite important in terms of health perspectives indicating a health risk to the populace through consumption.

There was a gradual increase in the number of leaves from week 2 to week 6 at different levels of contamination. However there was a significant change in the trend from week 6 to week 10 in $C$. olitorius and $A$. hybridus. The observed decrease in the numbers of leaves accounted for the chlorosis, necrosis and senescence of older leaves during the experimental period. The chlorosis spreads from older to younger leaves (Mengel et al., 1987). The significant increase recorded in the leaf area of the control plants is in conformity with the findings of Ashraf et al. (2000) while working on sorghum. It was revealed that sorghum samples from polluted sites had decreased leaf area as against the control.

The shoot height of $A$. hybridus and $C$. olitorius in the control region had the highest shoot height. These plants can be said to have devoted more of their nutrient for stem extension as apical dominance were more pronounced in them than $4 \mathrm{~m}$ and $6 \mathrm{~m}$ pollution levels (Thomas and Raper, 1983) this was in agreement with the report of Bouma and Nielson (2000) and Bonifas et al. (2005). The control plant had adequate nutrient supply and so do not require extra carbon for shoot growth. This 
observation was also repeated in the stem girth of the vegetable samples, this is because, and the control site had adequate nutrient supply and greater leaf area which increases the dry matter production in an optimal condition (Ologundudu et al., 2014).

The lowering of the moisture content under the control region may not be unconnected with the reduction in the production of photosynthesis as more carbon is devoted to root growth from both stem and leaf tissues (Morgan and Smith, 1981). Results of this study also reveals that moisture content of the soil correlates with the moisture content of the vegetables.

\section{Conclusion}

Findings from this research reveal that different vegetables accumulate and translocate variable amount of heavy metals from the soil into their tissues. Various health risk assessment and pollution indicators such as DIM, RHI, and RfD showed that the metal concentrations were close to unity (1), hence, it is not advisable to consume vegetable samples collected from this site based on the permissible limits as recommended by WHO. This study provided an insight into the current scenario of food crop contamination and possible future health risks of the populace. This study had to a larger extent emphasized the importance of physiological parameters in detecting the growth pattern of vegetable samples.

This study however recommended an urgent need to strictly monitor the metal scraps of the study area and to develop different strategies to prevent the accumulation of heavy metals in food crop that may ultimately minimise the chronic health risk to the exposed population. Hence, continuous monitoring of the soil, plant, and water quality are important pre-requisites for the prevention of potential health hazards to humans.
For further study, the concentration of heavy metals can be assessed after bioremediation strategy has been accomplished in order to ascertain the effectiveness of bioremediation at polluted site.

\section{Conflicts of interest}

Authors declare that they have no conflict of interests.

\section{References}

Agbenin, J. 0.; Danko, M.; Welp, G. Soil, vegetable compositional relationships of eight potentially toxic metals in urban garden fields from Northern Nigeria. Journal of the Science Food and Agriculture, v. 89, no. 1, p. 49-54, 2009. https://doi.org/10.1002/ jsfa.3409

Antonious, D. L.; Kochhar, G. K. Fall-out of lead and uptake by crops. Journal of Atmospheric Environment, v. 17, p. 693706, 2009.

Ashraf, M. H.; Raper, T. Enhancing food chain integrity: quality assurance mechanisms for air pollution impacts on fruit and vegetable system. Final Technical Report II submitted to Department of International Development, UK, 2000.

Bagdatioglu, D.; Aksoy, A. Heavy metal levels in vegetation in Turkey are within safe limits for $\mathrm{Cu}, \mathrm{Zn}, \mathrm{Ni}$ and exceeded for $\mathrm{Cd}$ and $\mathrm{Pb}$. Journal of Food Quality, v. 29, p. 252-265, 2010.

Bonifas, M. S.; Shaker, A.; Khaliq, M.A. Deposition of heavy metals on green leafy vegetables sold on road sides of Riyadh City, Saudi Arabia. Bulletin of Environmental Contamination and Toxicology, v. 75, p. 1020-1027, 2005.

Bouma T. J.; Nelson K. L. Sample preparation and scanning protocol for computerized analysis of root length and diameter. Plant and Soil, v. 218, p. 185-196, 2000.

Guerra, G. K.; Avci, H. Heavy metals in vegetables irrigated with waste waters in Gaziantep, Turkey: A review of causes and potential for human health risks. Fresenius Environmental Bulletin, v. 22, no. 1, p. 146151, 2012. 
Gupta, D. R.; Ashraf, S. D. The effects of growing bean diseases and pests. Netherlands Journal of Plant Pathology, v. 78, p. 12-18, 2010.

Gupta, N.; Khan, D. K.; Santra, S. C. An assessment of heavy metal contamination in vegetables grown in wastewater-irrigated areas of Titagarh, West Bengal, India. Bulletin of Environmental Contamination and Toxicology, v. 80 , no. 2, p. 115-118, 2008.

Honguchi, R.; Oguma, E.; Sasaki, S.; Miyamoto, K.; Ikeda, Y.; Machida, M. Dietary exposure to cadmium at close to the current provisional tolerable weekly intake does not affect renal function among female Japanese farmers. Environmental Research, v. 95, no. 1, p. 2031,2004

Ikeda, M.; Zhang, Z. W.; Shimbo, S.; Watanabe, T.; Nakatsuka, H.; Moon, C. S. Urban population exposure to lead and cadmium in East and South-East Asia. Science of the Total Environment, v.249, p. 373-384, 2010.

Lacatusu, G. P.; Sands, K.; Waters, M.; Wixson, B. G.; Dorward-King, E. Accumulation of heavy metals by vegetables grown in mine wastes. Environmental Toxicology and Chemistry, v. 19, no. 3, p. 600-607, 1996.

Luo, W. H.; Zhao, J. Z.; Ouyang, Z. Y.; Söderlund, L.; Liu, G. H. Impacts of sewage irrigation on heavy metal distribution and contamination in Beijing, China. Environment International, v. 31, no. 6, p. 805-812, 2011.

Mengel, T. Control of development in Chenopodium alnum L. by shade light. The effect of light quantity and light quality. New Phytologist, v. 88, p. 239-248, 1987.

Mohammad, I.; Horst, W. J. Effect of aluminium on lipid peroxidation, superoxide dismutase, and catalase and peroxidase activities in root tips of soybean (Glycine max). Physiologia Plantarum, v. 83, p. 463468, 2007.

Mohammed, M.; Rajani, S.; Mishra, A.; Rai, J. S. P. Utilization of okra gum for treatment of tannery effluent. International Journal of Polymeric Materials and Polymeric Biomaterials, v. 52, no. 11/12, p. 1049-1057, 2003.

Morgan, K. L.; Smith, J. R. Heavy metal contamination of soil and vegetables in suburban areas of Varanasi, India. Ecotoxicology and Environmental Safety, v. 66, no. 2, p. 258-266, 1981.

Oliver, G. H. Soil and plant factors influencing the accumulation of heavy metals by plants. Environmental Health Perspectives, v. 27, p. 149-159, 1997.

Ologundudu, A.; Adelusi, A. A.; Akinwale, R. 0. Effect of salt stress on germination and growth parameters of rice (Oryza sativa L.). Notulae Scientia Biologicae, v. 6, no. 2, p. 237-243, 2014.

Rattan, R. K.; Datta, S. P.; Chhonkar, P. K.; Suribabu, K. Long-term impact of irrigation with sewage effluents on heavy metal content in soils, crops and groundwater-a case study. Agriculture, Ecosystems \& Environment, v. 109, no. 310-322, 2005.

Rusan, M. J. M.; Hinnawi, S.; Rousan, L. Long term effect of wastewater irrigation of forage crops on soil and plant quality parameters. Desalination, v. 215 , no. $1 / 3$, p. $143-152$, 2007.

Singh, G. H.; Kumar, D. M. Impact of coal mine dump contaminated soils on elemental uptake by Spinacia oleracea (spinach). Journal of Environmental Science and Health, v. 41, p. 297-307, 2006.

Thomas, E. J.; Raper, P. B. Biological processes in drinking water treatment. Journal - American Water Works Association, v. 80, no. 8, p. 82-93, 1983.

Trumbo, P.; Yates, A. A.; Schlicker, S.; Poos, M. Dietary reference intakes: Vitamin A, vitamin $\mathrm{K}$, arsenic, boron, chromium, copper, iodine, iron, manganese, molybdenum, nickel, silicon, vanadium and zinc. Journal of the American Dietetic Association, v. 101, no. 3, p. 294-301, 2001.

USEPA - United State Environmental Protection Agency. Region 9. Preliminary remediation goals. 2006. Available from: <http://www.epa.gov/region09/waste/sfind /prg>. Accessed on: Aug. 07, 2012.

Volpe, H.; Chandrappa, G. T. Impact of heavy metal contamination of Bellandur Lake on soil and cultivated vegetation. Current Science, v. 91, p. 622-627, 2009.

WHO - World Health Organization. Guidelines for drinking water quality. Health criteria and other supporting information. Geneva: WHO, 1996. 
Wilson, A.H.; Pyatt, R. D. Heavy metal accumulations of 24 asparagus bean cultivars grown in soil contaminated with $\mathrm{Cd}$ alone and with multiple metals $(\mathrm{Cd}, \mathrm{Pb}$, and $\mathrm{Zn})$. Journal of Agricultural and Food Chemistry, v. 55, p. 1045-1052, 2007.

Zaidi, R. D.; Agrawal, M. Contaminated irrigation water and food safety for the sub-urban poor: Appropriate measures for monitoring and control. London, U.K.: Department of International Development, 2005.

Zaidi, S.; Satpati, S.; Nayek, S.; Garai, D. Effect of wastewater irrigation on vegetables in relation to bioaccumulation of heavy metals and biochemical changes. Environmental Monitoring and Assessment, v. 165, no. 1/4, p.169-177, 2005.
Zheljazkav, G.; Maduri, S. Heavy metals causing toxicity in animals and fishes. Research Journal of Animal, Veterinary and Fishery Sciences, v. 12, no. 2, p. 17-23, 2006.

Zhuang, N. S.; Kamala, C. T.; Raj, D.S.S. Assessing risk of heavy metals from consuming food grown on sewage irrigated soils and food chain transfer. Ecotoxicology and Environmental Safety, v. 69, no. 3, p. $513-524,2009$.

Zhuang, P.; McBride, M. B.; Xia, H.; Li, N.; Li, Z. Health risk from heavy metals via consumption of food crops in the vicinity of Dabao Shanmine, South China. Science of the Total Environment, v. 407, no. 5, p. 15511561, 2013. 